\title{
Mechanical Ventilation Down-Regulates Surfactant Protein A and Keratinocyte Growth Factor Expression in Premature Rabbits
}

\author{
ROBERT J. DIGERONIMO, SHAMIMUNISA B. MUSTAFA, RITA M. RYAN, ZOHARA Z. STERNBERG, \\ DANIEL J. ASHTON, AND STEVEN R. SEIDNER
}

\begin{abstract}
Department of Pediatrics [R.J.D.], Wilford USAF Hall Medical Center, Lackland AFB, Texas 78236; Department of Pediatrics [S.B.M., D.J.A., S.R.S.], University of Texas Health Science Center, San Antonio, Texas 78229; Department of Pediatrics [R.M.R., Z.Z.S.], State University of New York at Buffalo, Buffalo, New York 14222
\end{abstract}

\begin{abstract}
Surfactant-associated proteins (SP-A, SP-B, and SP-C) are critical for the endogenous function of surfactant. Keratinocyte growth factor (KGF) and vascular endothelial growth factor (VEGF) are key regulators of lung development. The objective of this study was to evaluate the effects of early mechanical ventilation on the expression of these important regulatory proteins in a preterm rabbit model. Premature fetuses were delivered at $29 \mathrm{~d}$ of gestation and randomized to necropsy at birth, i.e. no ventilation (NV), spontaneous breathing (SB), or mechanical ventilation (MV) for $16 \mathrm{~h}$. MV animals were further randomized to treatment with dexamethasone (dex). Our findings showed that SB rabbits increased their expression of SP-A mRNA and protein after birth compared with NV controls. MV significantly attenuated this response in the absence of dex. Exposure to dex elevated SP-B mRNA expression in both SB and MV rabbits. KGF protein levels were markedly increased in SB animals compared with MV counterparts. VEGF levels were similar in SB and MV animals, but were significantly increased compared with NV controls. These data suggest that MV alters surfactantassociated protein and growth factor expression, which may contribute to injury in the developing lung. (Pediatr Res 62: 277-282, 2007)
\end{abstract}

$\mathrm{T}$ he surfactant-associated proteins are important for optimal surfactant function and the hydrophobic apoproteins SP-B and SP-C are known to be essential for this process (1). SP-A is a hydrophilic apoprotein, the most abundant surfactant protein, and a member of the collectin family. Collectins are "pattern recognition molecules" that are important in host adaptive and innate immune responses (2,3). Reported contributions of SP-A to host defense include the ability to alter leukocyte function, bind a wide variety of microorganisms and aid in their killing, and interact directly with macrophages and lymphocytes to inhibit the production of proinflammatory cytokines (2).

KGF is a member of the fibroblast growth factor family (also known as FGF-7) that stimulates epithelial cell proliferation in the airways and alveoli (4). KGF is secreted in the lung mainly from fibroblasts, and its receptors have been

Received November 21, 2006; accepted April 24, 2007

The opinions expressed in this paper are solely those of the authors and do not represent the views of the United States Air Force, United States Army, Department of Defense, or the United States Government.

Correspondence: Robert J. DiGeronimo, M.D., 2220 Bergquist Drive, Suite 1, 859 MDOS/MMNP, Lackland Air Force Base, TX 78236-5300; e-mail: Robert.DiGeronimo@lackland.af.mil identified on alveolar epithelial cells (5). In adult respiratory distress syndrome animal models, the administration of KGF before injurious ventilation has been shown to protect the lung $(6,7)$. In addition to its role as an epithelial cell mitogen, KGF also has been shown to increase the expression of surfactant proteins and improve alveolar fluid clearance $(8,9)$.

VEGF is a potent endothelial cell mitogen that is important in the growth and regulation of lung vascular development and is expressed primarily in distal lung epithelial cells $(10,11)$. Human fetal lung explants treated with VEGF increase surfactant protein expression (12). A variety of growth factors, cell differentiation, and oxygen concentration are known to regulate VEGF expression (12,13). However, the role of VEGF in the pathophysiology of lung injury still remains to be established $(14,15)$.

Mechanical forces are known to be important in regulating growth and differentiation in the fetal and newborn lung $(16,17)$. Excessive alveolar distention, however, as often occurs in the preterm infant with MV, can contribute to ventilator-induced lung injury (VILI) $(18,19)$. In vitro work has demonstrated that exposure to mechanical stretch can alter both surfactant phospholipids and protein expression $(20,21)$.

In addition to mechanical stretch, it is well-known that corticosteroids can alter surfactant protein and growth factor expression in the developing lung; however, the majority of this work has been done using antenatal animal models or in vitro cell culture experiments $(11,22,23)$. Although there are some published data suggesting that corticosteroids can modify surfactant proteins in preterm infants with respiratory distress (24), the postnatal effects of corticosteroids, either alone or in combination with $\mathrm{MV}$, remain poorly understood.

Because most previous experiments examining VILI have used very high tidal volumes, there is a dearth of information describing how MV at normal tidal volumes may alter expression of surfactant and other regulatory proteins in the developing lung. Using a preterm rabbit animal model, we studied the effects of early MV versus SB, both in the presence or absence of corticosteroids, on surfactant protein and growth

\footnotetext{
Abbreviations: dex, dexamethasone; KGF, keratinocyte growth factor; MV, mechanical ventilation; NV, nonventilated; pro-SP-B (-C), prosurfactant protein B (C); SB, spontaneous breathing; SP-A (-B) (-C), surfactant protein A (B) (C); VILI, ventilator-induced lung injury
} 
factor expression, measuring KGF and VEGF as key regulators of epithelial and endothelial cells. We hypothesized that the use of positive pressure MV would attenuate the normal postnatal changes in expression of these proteins seen with negative pressure SB.

\section{METHODS}

The animal protocols used were reviewed and approved by the Animal Care and Use Committee of the University of Texas Health Science Center at San Antonio. All animals were maintained in an American Association for Accreditation Laboratory Animal-accredited facility.

Experimental design. New Zealand white rabbit fetuses from time-dated pregnancies (12 litters total) were delivered after cesarean section at $29 \mathrm{~d}$ of gestation $($ term $=31 \mathrm{~d})$. This model has been previously shown to produce preterm rabbits with significant surfactant deficiencies that require supplemental oxygen for survival (25). After delivery, animals were randomized to one of three groups: (1) NV (necropsy at birth), (2) SB, or (3) MV for $16 \mathrm{~h}$.

Delivery and ventilation. At birth, MV animals (after sedation) underwent tracheotomy and were randomized to treatment with dex $(5 \mathrm{mg} / \mathrm{kg})$. They were then placed in individual temperature-controlled plethysmographs driven by time-cycled, pressure-limited ventilation with $50 \%$ oxygen at 30 breaths/min. Peak inspiratory pressures were regulated to maintain tidal volumes at $10 \mathrm{~mL} / \mathrm{kg}$ in an effort to maintain $\mathrm{pCO}_{2}$ values around 40 torr as demonstrated in previous studies using this model (25). SB rabbits were placed in an incubator at $37^{\circ} \mathrm{C}$ flooded with $50 \%$ oxygen. Dex $(0.5 \mathrm{mg} / \mathrm{kg})$ was delivered to selected animals (both MV and SB) via intracardiac injection shortly after birth. Drug or saline was injected via a 29-gauge needle on an insulin syringe after withdrawal of free flowing blood. All study animals were necropsied at $16 \mathrm{~h}$ of life, at which time lung tissue was isolated and frozen in liquid nitrogen.

Northern blot analysis. Total lung RNA was isolated using Trizol reagent (GIBCO, Gaithersburg, MD). RNA was size-fractionated by electrophoresis on a $0.8 \%$ agarose $/ 2.2 \mathrm{M}$ formaldehyde gel under denaturing conditions and transferred using a PosiBlot (Stratagene, La Jolla, CA) onto a Magna nylon membrane (Microns Separations Inc., Westborough, MA). RNA was immobilized by UV cross-linking. Membranes were then hybridized with rabbit specific ${ }^{32} \mathrm{P}$-labeled $\mathrm{CDNA}$ probes for $\mathrm{SP}-\mathrm{A},-\mathrm{B}$, and $-\mathrm{C}$ and then reprobed with $18 \mathrm{~S}$ rRNA. Signal intensity was quantified using densitometry (Image Quant software).

Western blot analysis. Protein was isolated after homogenization in lysisbuffered saline (Tris-HCl $50 \mathrm{mM}, \mathrm{pH} 7.4$, triethanolamine-buffered saline) containing $5 \mathrm{mM}$ Na-ethylenediaminetetraacetic acid (EDTA), $5 \mathrm{mM} \mathrm{Na}$ ethyleneglycol-bis-( $\beta$-aminoethylether)- $\mathrm{N}, \mathrm{N}, \mathrm{N}^{\prime}, \mathrm{N}^{\prime}$-tetraacetic acid (EGTA), leupeptin $(1 \mu \mathrm{M})$, pepstatin $\mathrm{A}(1 \mu \mathrm{M})$, aprotonin $(1 \mu \mathrm{M})$, and phenylmethylsulfonyl fluoride (PMSF) $(1 \mu \mathrm{M})$. Protein concentrations were determined using the BioRad DC protein assay (Hercules, CA). Total protein $50 \mu \mathrm{g}$ was subjected to sodium dodecyl sulfate-polyacrylamide gel electrophoresis resolution, and the separated proteins were transferred electrophoretically to polyvinylidene difluoride membranes (Millipore, Bedford, MA) and incubated with primary antibodies for SP-A, pro-SP-B and pro-SP-C (Chemicon, Temecula, CA). Because both SP-B and SP-C are secreted as proproteins, the pro-SP antibodies were chosen for analysis. Blots were incubated with secondary antibody conjugated to horseradish peroxidase and visualized using enhanced chemiluminescence. The relative intensities of the bands were quantified by densitometry.

Protein tissue enzyme-linked immunosorbent assay (ELISA). Lung tissue was homogenized and the supernatant was assayed for total protein, VEGF, and KGF content. Briefly, 100- to 200-mg samples of whole lung tissue was homogenized in ice cold lysis buffer $(0.3 \mathrm{~mL}$ for $100 \mathrm{mg}, 0.7 \mathrm{~mL}$ for $200 \mathrm{mg}$ tissue) containing $150 \mathrm{mM} \mathrm{NaCl}, 50 \mathrm{mM}$ Tris- $\mathrm{Hcl}, 25 \mathrm{mM} \beta$-glycerophosphate, $25 \mathrm{mM} \mathrm{NaF}, 2 \mathrm{mM}$ EDTA, $2 \mathrm{mM}$ EGTA, $0.5 \mu \mathrm{g} / \mathrm{mL}$ leupeptin, 0.1 $\mathrm{mM}$ Na-orthovanadate and $0.1 \mathrm{mM}$ PMSF. The homogenates were centrifuged at $4^{\circ} \mathrm{C}$ at $1000 \mathrm{x} g$ for $10 \mathrm{~min}$ and supernatants collected. The resulting pellet was resuspended and respun, and the supernatant was combined with the initial supernatant. Total protein concentration was determined using a Lowry assay (BioRad, Hercules, CA). VEGF and KGF concentrations were determined using Quantikine (R\&D Systems, Minneapolis MN, VEGF cat \# DVE00, KGF cat \#DKG00) Human VEGF immunoassay, which is a sandwich ELISA, and human KGF immunoassay, a solid-phase ELISA.

Data analysis. Terminal blood gases were performed on all animals, and those rabbits with a $\mathrm{pH}<7.0$ or $\mathrm{PCO}_{2}$ value $>65 \mathrm{~mm} \mathrm{Hg}$ were excluded. There was approximately $5 \%$ and $20 \%$ mortality, respectively, associated with SB or MV before the study endpoint of $16 \mathrm{~h}$. All data are presented as means $\pm \mathrm{SE}$. For analysis, there were six animals per study group (except for SB animals, no dex, which had eight). A $t$ test was initially done between NV and SB animals, followed by two-way analysis of variance (ANOVA) on all groups. This was followed by pairwise multiple comparison using the Holm-Sidak method where appropriate (SigmaStat, Richmond, CA). A $p$ value of $<0.05$ was considered statistically significant.

\section{RESULTS}

SB preterm rabbits had increased lung tissue expression of SP-A mRNA after $16 \mathrm{~h}$ of life compared with NV controls (Fig. $1 ; p<0.05$ ). This response was significantly attenuated in MV animals (Fig. 1, $p<0.05$ ). Dex administration at birth resulted in increased SP-A mRNA in MV animals similar to those levels seen with SB (Fig. 1; $p<0.05$ ). Interestingly, we did not observe a significant increase in SP-A mRNA expression in SB animals treated with dex for $16 \mathrm{~h}$ compared with untreated SB counterparts.

Unlike SP-A, neither SP-B nor SP-C mRNA levels significantly increased after $16 \mathrm{~h}$ in SB animals compared with NV controls (Figs. 2 and 3). Additionally, MV in the absence of any other treatment did not alter mRNA expression of either of these SP genes. Dex treatment did increase SP-B mRNA in both SB and MV animals (Fig. 2; $p<0.05$ ). For SP-C, none of the study groups was statistically different versus $\mathrm{NV}$ controls (Fig. 3).

SP-A protein levels were increased in SB animals compared with NV controls (Fig. 4; $p<0.05$ ). Similar to mRNA expression, SP-A protein tissue levels significantly decreased after $16 \mathrm{~h}$ of MV compared with SB animals (Fig. 4; $p<$ 0.05). Surprisingly, dex treatment did not alter the level of SP-A protein in either the SB or MV animals. Both pro-SP-B and pro-SP-C levels were significantly higher in all study groups at $16 \mathrm{~h}$ compared with NV controls $(p<0.05)$, but were not affected by MV or dex treatment (Figs. 5 and 6).

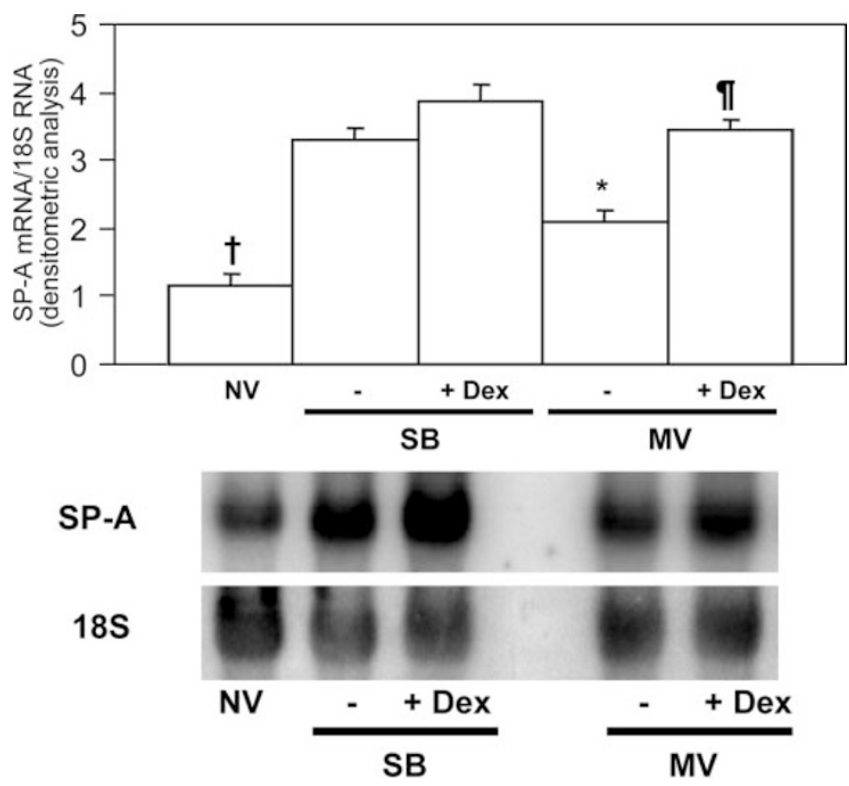

Figure 1. SP-A mRNA analysis comparing SB with MV animals. SB animals had a significant increase in SP-A mRNA compared with NV controls. By two-way ANOVA, MV attenuated this postnatal increase in SP-A compared with SB. Dex alone did not alter SP-A levels during SB, but with MV, did restore SP-A to similar levels found with SB. †Compared with all other groups, $p<0.05$; *compared with $\mathrm{SB}, p<0.05$; IIcompared with MV-dex, $p<0.05$. 

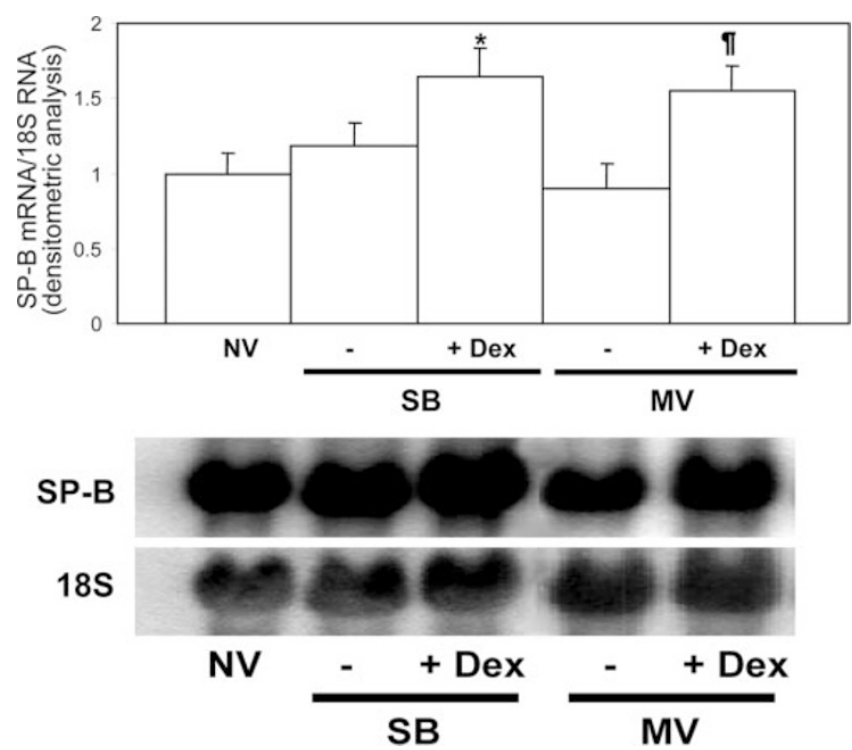

Figure 2. SP-B mRNA analysis comparing SB with MV animals. SP-B mRNA was not altered in SB animals compared with NV controls. By two-way ANOVA, MV did not affect SP-B levels, but dex did increase SP-B mRNA in both SB and MV groups. *Compared with SB-dex, $p<0.05$; Ifcompared with MV-dex, $p<0.05$.
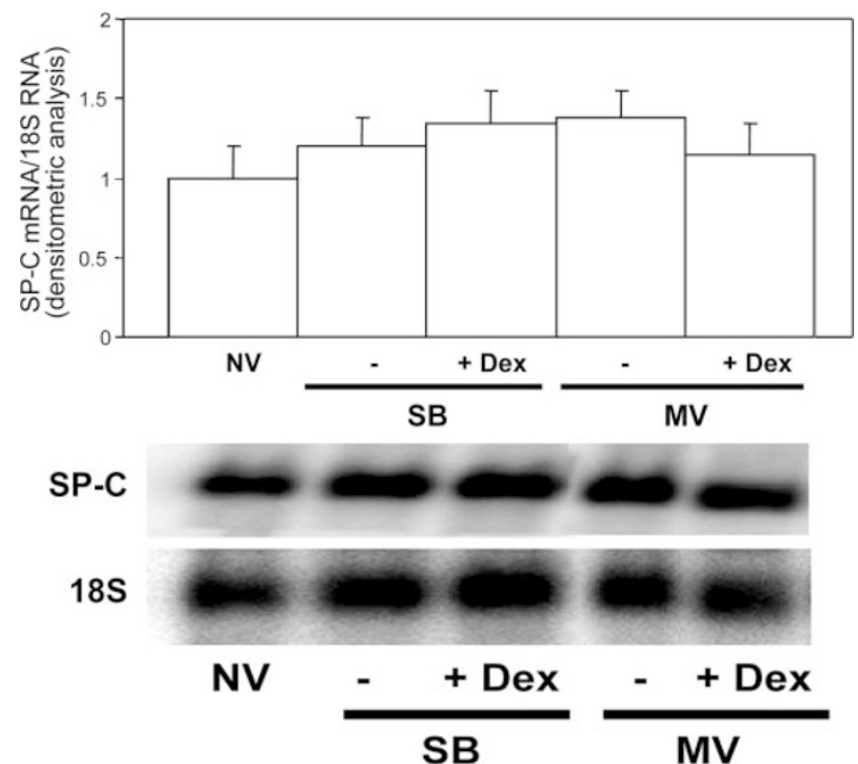

Figure 3. SP-C mRNA analysis comparing SB to MV animals. SP-C mRNA was not altered in SB animals compared with NV controls. Additionally, by two-way ANOVA, neither dex nor MV altered SP-C expression.

The results of the protein lung tissue levels of KGF and VEGF protein are shown in Figures 7 and 8, respectively. KGF levels were elevated in SB fetuses compared with NV counterparts but not significantly. Interestingly, we observed that whole lung protein levels of KGF were significantly decreased in all MV groups $( \pm$ dex $)$ when compared with either NV controls or SB animals $(p<0.01)$. Significantly higher levels of VEGF protein were detected in SB and MV animals after $16 \mathrm{~h}$ compared with $\mathrm{NV}$ counterparts, but there was no difference between SB and MV animals (Fig. 8; $p<0.01)$.

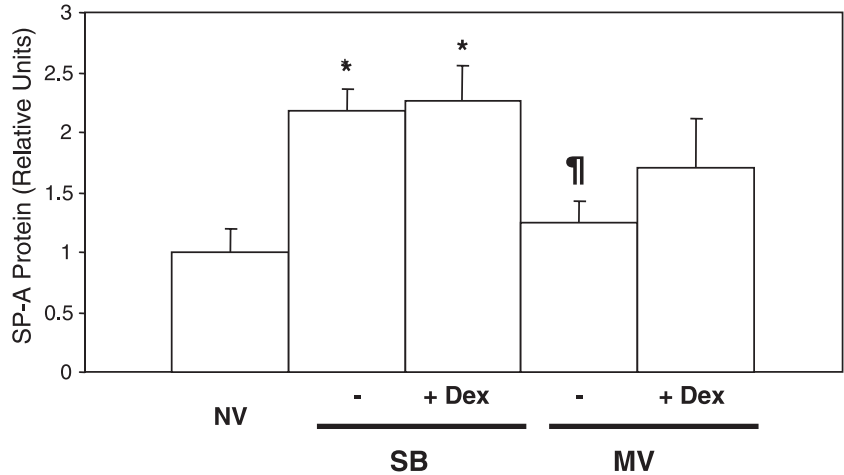

Figure 4. SP-A protein analysis comparing SB with MV animals. SB animals had a significant increase in SP-A protein compared with NV controls. By two-way ANOVA, similar to SP-A mRNA, MV attenuated SP-A protein expression compared with SB. Dex, however, did not alter SP-A protein with either SB or MV. *Compared with NV, $p<0.05$; I[compared with SB, $p<$ 0.05 .

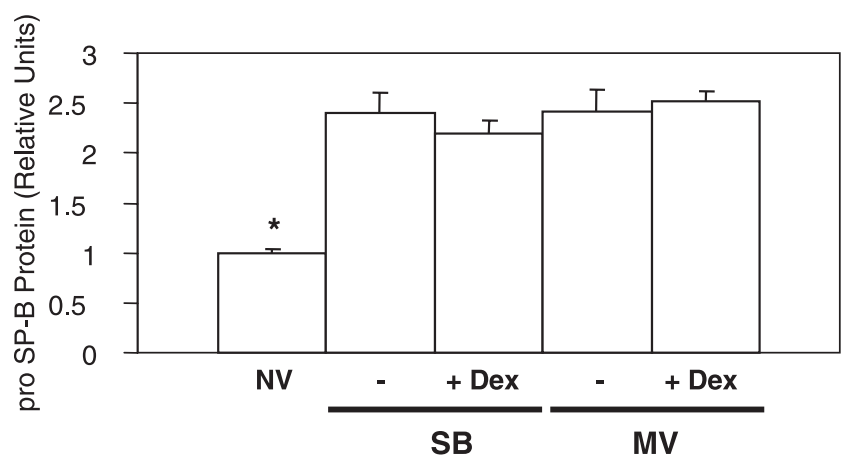

Figure 5. Pro-SP-B protein analysis comparing SB with MV animals. SB animals had a significant increase in Pro-SP-B protein compared with NV controls. By two-way ANOVA, there was no effect of either MV or dex on ProSP-B expression. *NV compared with all other groups, $p<0.05$.

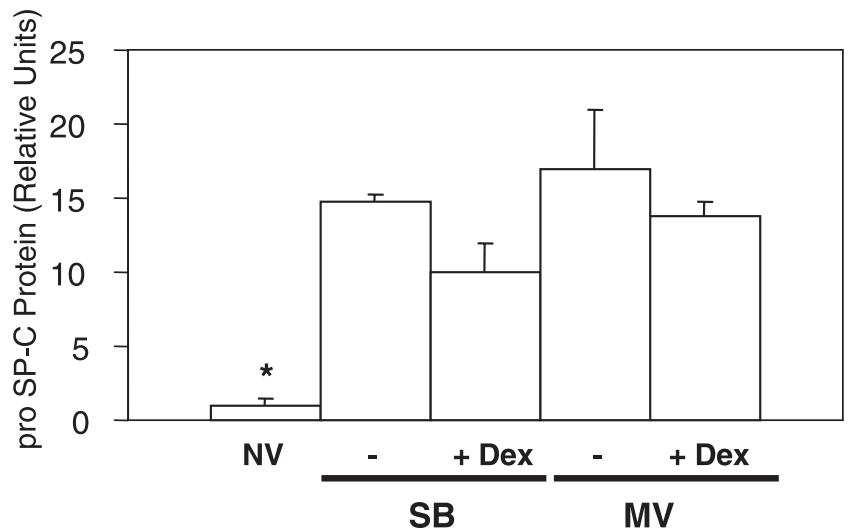

Figure 6. Pro-SP-C protein analysis comparing SB with MV animals. SB animals had a significant increase in Pro-SP-C protein compared with NV controls. By two-way ANOVA, there was no effect of either MV or dex on ProSP-C expression. *NV compared with all other groups, $p<0.05$.

\section{DISCUSSION}

Although the ability of mechanical force to regulate gene expression in distal lung epithelium has been well established, cellular response often varies extensively between in vitro experiments $(16,17)$. It remains unclear how the effects of stretch translate in vivo, particularly with MV of the immature 


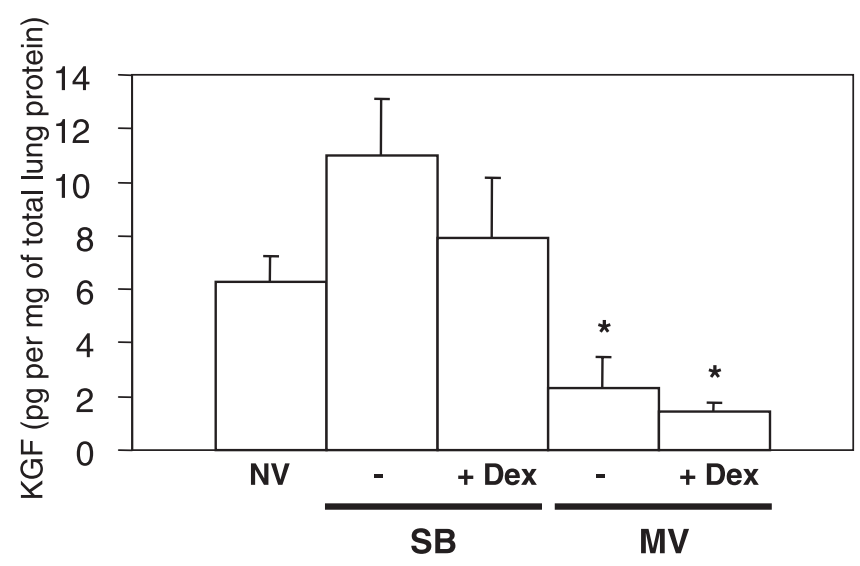

Figure 7. KGF protein ELISA comparing SB with MV animals. KGF protein was not altered in SB animals compared with NV controls. By two-way ANOVA, although treatment with dex did not alter KGF, MV did significantly decrease KGF expression. *All MV groups compared with SB and NV, $p<0.01$.

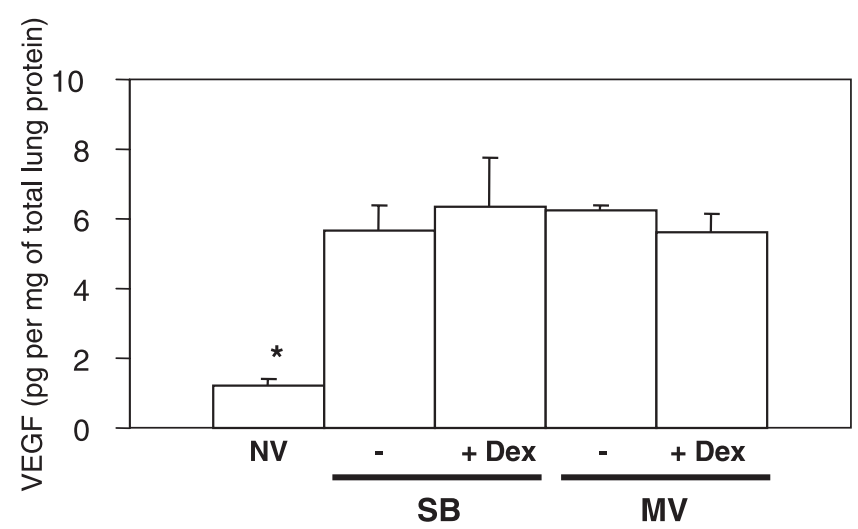

Figure 8. VEGF protein ELISA comparing SB with MV animals. VEGF protein was significantly up-regulated in SB animals compared with $\mathrm{NV}$ controls. By two-way ANOVA, there was no effect of either MV or dex on VEGF expression. *Compared with all other groups, $p<0.01$.

lung. SPs have been previously shown to be decreased in humans with adult respiratory distress syndrome (26). Using a preterm baboon model of bronchopulmonary dysplasia (BPD), King et al. (27) showed that decreased SP-A mRNA and protein were associated with the development of BPD. In another study of human preterm infants, Hallman et al. (28) noted low air space levels of SP-A in infants who went on to develop BPD later.

A recent paper published by Bohlin et al. (29) used a model similar to ours comparing the effects of MV with those of SB on tissue distribution of surfactant and lung function in preterm rabbits. After short-term ventilation, they found that MV decreased lung tissue association of exogenously administered surfactant and that this was associated with increased surfactant inactivation compared with SB animals. The only previous in vivo study specifically measuring the effects of MV on surfactant protein expression was done by Woods et al. (30). Preterm sheep were mechanically ventilated for variable time periods from $45 \mathrm{~min}$ to $10 \mathrm{~h}$. They found that both SP-A and SP-C mRNA in NV controls increased from 120 to $132 \mathrm{~d}$ of gestation. In those animals MV after birth for $10 \mathrm{~h}$, SP-A and
SP-B mRNA increased. They also studied the effect of exogenous surfactant and found no effect on SP expression.

The addition of a SB group in our study allowed us to better explore the potential isolated effects of positive pressure MV on lung protein regulation during postnatal adaptation. Similar to findings in the Woods et al. study in later gestation lambs, we found that SP-A mRNA increased with MV from birth. However, this increase in SP-A mRNA was significantly lower in MV compared with SB animals. Additionally, we found that SP-A protein levels were elevated after $16 \mathrm{~h}$ only in $\mathrm{SB}$ animals. Our findings support that MV attenuates the increased expression of both SP-A mRNA and protein that otherwise occurs in the lungs of SB preterm animals after birth. This relative deficiency of SP-A associated with MV may be important in the early process of VILI and later chronic lung disease, as has been suggested by previous investigators $(27,28)$.

In our study, we did not observe any changes in SP-B or SP-C mRNA expression after $16 \mathrm{~h}$ of postnatal ventilation compared with NV controls. However, pro-SP-B and proSP-C protein levels increased severalfold after $16 \mathrm{~h}$ in both SB and MV animals. Given that lung mRNA was relatively high in NV controls for both of these SPs, increases in mRNAs of these proteins may have occurred transiently before our measurements at $16 \mathrm{~h}$. Alternatively, a selective increase in translation may have occurred during postnatal adaptation and ventilation.

Although corticosteroids are known to play an important role in surfactant synthesis, the exact mechanism whereby they exert their effect on surfactant protein gene regulation in the immature lung has not been well defined given the complexity of their interaction $(1,31)$. The use of dex in our study did result in a significant increase in SP-A mRNA with MV, stimulating levels to those found in SB animals. SP-A protein trended higher in lung tissue when MV animals were treated with dex but did not reach statistical significance. Perhaps measurement at a later time point would have demonstrated an increase in tissue protein as well. Unfortunately, anti-rabbit SP-D antibody was not available at the time of this study, as this would be an intriguing protein to evaluate due to its important role in surfactant homeostasis, host defense, and BPD.

A number of both cell and animal studies have demonstrated increased SP-B expression after corticosteroid treatment $(23,32)$. In our experiments, SP-B mRNA levels were increased with the addition of postnatal dex in both SB and MV rabbits. The expression of pro-SP-B protein increased from birth in all groups but was not inhibited by MV nor increased with dex. These differential responses between SP-B mRNA and pro-SP-B protein expression are consistent with literature using human fetal lung explants (32). These experiments suggest that SP-B gene expression is regulated primarily at the level of translation or protein stability, whereas glucocorticoids appear to act transcriptionally.

Additionally, we explored the effects of both SB and MV on KGF and VEGF expression in lung tissue. Compared with NV controls and SB animals, KGF levels were significantly decreased for all MV groups and were not altered by treatment 
with dex. As previously discussed, KGF is protective of lung injury in multiple animal models, and in several studies, levels of KGF measured in lung fluid have been predictive of outcome $(33,34)$. Danan et al. (34) found that high tracheal aspirate levels of KGF taken from premature infants within the first $5 \mathrm{~d}$ of life were predictive of the absence of later development of BPD. Given the potential protective effect of $\mathrm{KGF}$, it follows that the lack of KGF in the air space may predispose premature infants to lung injury.

KGF in a number of in vitro studies using lung epithelial cells has demonstrated the ability to augment the expression of surfactant, including the surfactant-associated proteins $(8,35)$. Of interest is the finding from our study that both lung KGF and SP-A were decreased with MV, and it is possible that these low levels of KGF contributed to attenuated SP-A expression. This association has not been previously described in vivo either in the developing or mature lung.

Corticosteroid use in vitro has been shown to enhance the expression of KGF in the lung (36). A recent study using cultured fetal rat type II cells treated with both KGF and dex noted a synergistic increase of both SP-A and SP-B mRNA (37). SP-A protein was additionally increased threefold in cells treated with both. The effect of dex on KGF release in vivo into the lung tissue or air space has not been previously reported. In our study, the addition of dex did not result in increased KGF protein in the lung tissue of either SB or MV animals after $16 \mathrm{~h}$, but with a longer duration of exposure, protein expression might have been altered.

We did not find differences in lung VEGF levels between SB and MV animals in our study. VEGF is known to be expressed in the distal airway epithelium of the fetal and postnatal lung $(10,11)$. Previous work using type II cells isolated from newborn rabbits $1 \mathrm{~d}$ to $5 \mathrm{wk}$ of age noted the presence of VEGF mRNA in these animals (38). The multiplefold increase in VEGF observed in our study after $16 \mathrm{~h}$ in both SB and MV animals shows that the preterm lung can rapidly increase VEGF expression and/or release after birth.

Previous in vitro work has shown that VEGF expression is inhibited in the presence of corticosteroids, whereas others have shown an increase in fetal human lung explants $(10,39)$. Bhatt et al. (10) reported that 6-d-old term newborn mice had increased lung VEGF mRNA and/or protein after $3 \mathrm{~d}$ of dex treatment. In our preterm model, we did not see any change in lung tissue VEGF protein with dex. This may be reflective of the short treatment interval or perhaps a differential response between preterm and term animals to corticosteroids.

The main limitation to our study was the restriction to a single time point at $16 \mathrm{~h}$, which was the upper limit for a high survival rate of MV rabbits. Therefore, changes in SPs, KGF, and VEGF may have been minimized. Additionally, given that NV rabbits were delivered prematurely, it is possible that any changes observed in control versus study animals, at least in part, may have occurred secondary to maturation and not postnatal ventilation. A major strength of our model was the ability to randomize and compare the postnatal adaptation of mechanically and spontaneously ventilated groups within individual preterm litters to minimize several potential covariates. Despite relatively low ventilatory requirements with mild respiratory distress that normally would not be associated with significant degrees of lung injury, we were able to identify some key adaptive changes in surfactant proteins and growth factors during the early postnatal course that were inhibited by positive pressure mechanical ventilation.

Concerning the use of postnatal corticosteroids, it is important to note that their use for the prevention or treatment of BPD in premature infants is not presently recommended (40). The results from our study therefore should not be interpreted as justification for their clinical use, but perhaps will add to a better understanding of the mechanism(s) of their positive treatment effects to rationally develop more targeted therapies that might have fewer adverse effects.

In summary, our study has shown that the use of early MV as compared with SB in preterm rabbits decreases the expression of both SP-A and KGF. Although the use of corticosteroids selectively increased SP levels during postnatal ventilation, they did not affect the expression of either KGF or VEGF. VEGF protein levels were up-regulated shortly after birth, but were not altered by the style of ventilation. Further work needs to be done to explore the effects of MV and its interactions with SPs, corticosteroids, growth factors, and other cytokine mediators in the postnatal developing lung.

Acknowledgments. The authors thank Lori Nielsen for her technical expertise in assisting with the KGF and VEGF ELISAs.

\section{REFERENCES}

1. Notter RH 2000 Functional composition and component biophysics of endogenous lung surfactant. In: Lenfant $\mathrm{C}$ (ed) Lung surfactants: basic science and clinical applications. Marcel Dekker, New York, pp 185-188

2. Wright JR, Borron P, Brinker KG, Folz RJ 2001 Surfactant protein A: regulation of innate and adaptive immune responses in lung inflammation. Am J Respir Cell Mol Biol 24:513-517

3. McCormack FX, Whitsett JA 2002 The pulmonary collectins, SP-A and SP-D, orchestrate innate immunity in the lung. J Clin Invest 109:707-712

4. Ware LB, Matthay MA 2002 Keratinocyte and hepatocyte growth factors in the lung: roles in lung development, inflammation, and repair. Am J Physiol Lung Cell Mol Physiol 282:L924-L940

5. Rubin JS, Osada H, Finch PW, Taylor WG, Rudikoff S, Aaronson SA 1989 Purification and characterization of a newly identified growth factor specific for epithelial cells. Proc Natl Acad Sci U S A 86:802-806

6. Welsh DA, Summer WR, Dobard EP, Nelson S, Mason CM 2000 Keratinocyte growth factor prevents ventilator-induced lung injury in an ex vivo rat model. Am J Respir Crit Care Med 162:1081-1086

7. Oswari J, Matthay MA, Margulies SS 2001 Keratinocyte growth factor reduces alveolar epithelial susceptibility to in vitro mechanical deformation. Am J Physiol Lung Cell Mol Physiol 281:L1068-L1077

8. Sugahara K, Rubin JS, Mason RJ, Aronsen EL, Shannon JM 1995 Keratinocyte growth factor increases mRNAs for SP-A and SP-B in adult rat alveolar type II cells in culture. Am J Physiol 269:L344-L350

9. Guery BP, Mason CM, Dobard EP, Beaucaire G, Summer WR, Nelsen S 1997 Keratinocyte growth factor increases transalveolar sodium resorption in normals and injured rat lungs. Am J Respir Crit Care Med 155:1777-1784

10. Bhatt AJ, Amin SB, Chess PR, Watkins RH, Maniscalco WM 2000 Expression of vascular endothelial growth factor and Flk-1 in developing and glucocorticoidtreated mouse lung. Pediatr Res 47:606-613

11. Zeng X, Wert SE, Federici R, Peters KG, Whitsett JA 1998 VEGF enhances pulmonary vasculogenesis and disrupts lung morphogenesis in vivo. Dev Dyn 211:215-227

12. Brown KR, England KM, Goss KI, Snyder JM, Acarregui MJ 2001 VEGF induces airway epithelial cell proliferation in human fetal lung in vitro. Am J Physiol Lung Cell Mol Physiol 281:L1001-L1010

13. Boussat S, Eddahibi S, Coste A, Fataccioli V, Gouge M, Housset B, Adnot S, Maitre B 2000 Expression and regulation of vascular endothelial growth factor in human pulmonary epithelial cells. Am J Physiol Lung Cell Mol Physiol 279:L371-L378

14. Mura M, dos Santos C, Stewart D, Liu M 2004 Vascular endothelial growth factor and related molecules in acute lung injury. J Appl Physiol 97:1605-1617

15. Maniscalco WM, Watkins RH, Pryhuber GS, Bhatt A, Shea C, Huyck H 2002 Angiogenic factors and alveolar vasculature: development and alterations by injury in very premature baboons. Am J Physiol Lung Cell Mol Physiol 282:L811-L823 
16. Dobbs LG, Gutierrez JA 2001 Mechanical forces modulate alveolar epithelial phenotype expression. Comp Biochem Physiol A Mol Integr Physiol 129:261-266

17. Liu M, Post M 2000 Invited review: mechanochemical signal transduction in the fetal lung. J Appl Physiol 89:2078-2084

18. Dos Santos CC, Slutsky AS 2000 Invited review: mechanisms of ventilator-induced lung injury: a perspective. J Appl Physiol 89:1645-1655

19. Tremblay LN, Slutsky AS 1998 Ventilator-induced lung injury: from barotrauma to biotrauma. Proc Assoc Am Physicians 110:482-488

20. Wirtz HR, Dobbs LG 1990 Calcium mobilization and exocytosis after one mechanical stretch of lung epithelial cells. Science 250:1266-1269

21. Sanchez-Esteban J, Tsai SW, Sang J, Qin J, Torday JS, Rubin LP 1998 Effects of mechanical forces on lung-specific gene expression. Am J Med Sci 316:200-204

22. Schellhase DE, Shannon JM 1991 Effects of dexamethasone on expression of SP-A, SP-B and SP-C in the fetal rat lung. Am J Respir Cell Mol Biol 4:304-312

23. Ballard PL, Ning Y, Polk D, Ikegami M, Jobe AH 1997 Glucocorticoid regulation of surfactant components in immature lambs. Am J Physiol 273:L1048-L1057

24. Wang JY, Yeh T, Lin Y, Miyamura K, Holmskov K, Reid KB 1996 Measurement of pulmonary status and surfactant protein levels during dexamethasone treatment of neonatal respiratory distress syndrome. Thorax 51:907-913

25. Seidner S, Rider E, Jobe A, Yamada T, Ikegami M 1992 Effects of antenatal thyrotropin-releasing hormone, antenatal corticosteroids, and postnatal ventilation on surfactant mobilization in premature rabbits. Am J Obstet Gynecol 166:15511559

26. Lewis JF, Jobe AH 1993 Surfactant and the adult respiratory distress syndrome. Am Rev Respir Dis 147:218-233

27. King RJ, Coalson JJ, deLemos RA, Gerstmann SR, Seidner SR 1995 Surfactant protein A deficiency in a primate model of bronchopulmonary dysplasia. Am J Respir Crit Care Med 151:1989-1997

28. Hallman M, Merritt TA, Akino T, Bry K 1991 Surfactant protein A, phosphatidylcholine, and surfactant inhibitors in epithelial lining fluid. Am Rev Respir Dis 144:1376-1384

29. Bohlin K, Bouhafs R, Jarstrand C, Cursedt T, Blennow M, Robertson B 2005 Spontaneous breathing or mechanical ventilation alters compliance and tissue association of exogenous surfactant in preterm newborn rabbits. Pediatr Res 57:624-630
30. Woods E, Ohashi T, Polk D, Ikegami M, Ueda T, Jobe AH 1995 Surfactant treatment and ventilation effects on SP-A, SP-B, and SP-C mRNA levels in preterm lamb lungs. Am J Physiol 269:L209-L214

31. Mendelson CR, Alcorn JL, Gao E 1993 The pulmonary surfactant protein genes and their regulation in fetal lung. Semin Perinatol 17:223-232

32. Beers MF, Shuman H, Liley HG, Floros J, Gonxales LW, Yue N, Ballard PL 1995 Surfactant protein B in human fetal lung: developmental and glucocorticoid regulation. Pediatr Res 38:668-675

33. Stern JB, Fierobe L, Paugam C, Rolland C, Dehoux M, Petiet A, Dombret MC, Mantz J, Aubier M, Crestani B 2000 Keratinocyte growth factor and hepatocyte growth factor in bronchoalveolar lavage fluid in acute respiratory distress syndrome patients. Crit Care Med 28:2326-2333

34. Danan C, Franco ML, Jarreau PH, Dassieu G, Chailley-Heu B, Bourbon J, Delacourt C 2002 High concentrations of keratinocyte growth factor in airways of premature infants predicted absence of bronchopulmonary dysplasia. Am J Respir Crit Care Med 165:1384-1387

35. Mason RJ, Lewis MC, Edeen KE, McCormick-Shannon K, Nielsen LD, Shannon JM 2002 Maintenance of surfactant protein A and D secretion by rat alveolar type II cells in vitro. Am J Physiol Lung Cell Mol Physiol 282:L249-L258

36. Chelly N, Henrion A, Pinteur C, Chailley-Heu B, Bourbon JR 2001 Role of keratinocyte growth factor in the control of surfactant synthesis by fetal lung mesenchyme. Endocrinology 142:1814-1819

37. Mouhieddine-Gueddiche OB, Pinteur C, Chailley-Heu B, Barlier-Mur AM, Clement A, Bourbon JR 2003 Dexamethasone potentiates keratinocyte growth factorstimulated SP-A and SP-B gene expression in alveolar epithelial cells. Pediatr Res 53:231-239

38. Maniscalco WM, Watkins RH, D’Angio CT, Ryan RM 1997 Hyperoxic injury decreases alveolar epithelial cell expression of vascular endothelial growth factor (VEGF) in neonatal rabbit lung. Am J Respir Cell Mol Biol 16:557-567

39. Nauck M, Karakiulakis G, Perruchoud AP, Papakonstantinou E, Roth M 1998 Corticosteroids inhibit the expression of the vascular endothelial growth factor gene in human vascular smooth muscle cells. Eur J Pharmacol 341:309-315

40. Committee on Fetus and Newborn 2002 Postnatal corticosteroids to treat or prevent chronic lung disease in preterm infants. Pediatrics 109:330-338 